\title{
'These bookes, as I heare, are all cawled in': Dance and Choreographic Records from the Stuart Masques
}

In the first four decades of the seventeenth century, masques became an expected and commonly occurring part of the Christmas and Twelfth Night festivities and entertainments at the English court, as well as part of the celebrations to mark important state events such as royal or noble weddings. The performances themselves were usually so well attended that the hall was overcrowded. On occasions a masque was repeated a few days later and those who were not able to gain entry to witness a performance for themselves were always eager to hear details of the spectacle. In 1636, for example, Heywood's Loves Mistresse was presented three times in eight days before the king, queen, and foreign ambassadors at the Phoenix Theatre in Drury Lane, ${ }^{\mathrm{I}}$ while ten days separated the two performances of Shirley's The Triumph of Peace, first performed at Whitehall before Charles I and Henrietta Maria and then repeated on I3 February I634 at Merchant Taylor's Hall: 'The mask ... was so well performed and well lyked as theyr Majestyes were after pleased to invite themselves to a supper at the Lord Maiors for a second syght of it there. ... [On I3 February] theyr majestyes and some 70 great lordes and ladies and other persons of quality were entertayned at a most plentyful supper in the lord maiors house and, after this, a ball and the mask at Merchant Taylors Hall'. ${ }^{2}$ Printed and manuscript copies of the masque texts found readers both inside and outside court circles, and, as scholars such as Lauren Shohet have demonstrated, commercial publishers and booksellers expressed a lively commercial interest in the genre'. 3 The 1634 masque The Triumph of Peace, for example, created such a storm of public interest that it was printed and then reprinted three times in one year, leading to a probable output of three thousand copies. ${ }^{4}$ Masque texts circulated through a variety of distribution networks in Jacobean and Caroline England for the benefit of readers eager to learn about the latest political events and the political opinions and policies of the major protagonists in the court. At a masque performance the vast major- 
ity of the time was occupied with dancing; yet the choreographies - even the specially choreographed masque dances as opposed to the revels - do not appear in the printed or manuscript masque texts. The obvious question, therefore, is why were the dances seemingly ignored in the printed and manuscript masque texts that we know today, given that contemporary interest in the dances and the dance performances was so high?

The most obvious explanation regarding the seemingly total absence of choreographic records for the English masques produced by the court, in private homes, and by the Inns of Court, is that no easy form of choreographic notation existed at this period, especially for group dances with up to a dozen participants. Indeed, Barbara Ravelhofer has commented that the dance masters in England seem to have been allergic to dance description and writing, and that the learning of new dances was carried out by demonstration, imitation, and practise. 5 The most common form of notation at this time was a written description, but such description was very lengthy as it did far more than refer to a general description of geometrical figures, as did the sentences on the masque dances found in the masque texts. The form of dance notation as a written description, which first appeared in the mid-fifteenth-century Italian dance treatises, gave the number of dancers and the steps performed by those dancers, as well as the direction(s) in which those steps were made, and the relationship between the dancers as they progressed through a choreography. After an explanation of the opening diagram, the first few sentences of Emilio de' Cavalieri's published choreography of the final ballo in the 1589 Florentine intermedi reads:

This dance will be begun by seven persons, that is, four women and three men ... All together these seven will make a riverenza with the left foot, and the continenze [starting by moving to] the left hand side, and a riverenza to the left, and two cangi [starting] with the left foot, and a seguito trangato forwards and one backwards. Then all the seven will move in a circle to the left hand side with four spezzate [starting] with the left foot, and another four scorse returning to their place. ${ }^{6}$

The choreography then continues in the same manner for another sixty-two lines, or three pages of printed text.7 Only two diagrams of the positions of the seven principal dancers, and twenty 'chorus' dancers at two precise moments appear in this publication. If the printed text had provided diagrams that showed every part of the floor plan, then at least sixty diagrams would have been required for this 253 -bar choreography. ${ }^{8}$ Contemporaries 
recognized the problem of the space required to print diagrams of all the dances in a spectacle. In the published account of the 1620 dance spectacle held in Naples, diagrams of the twenty-four dance figures for the twenty-four noble gentlemen dancers were included, along with the text of songs and some of the musical pieces. As the text states, however, the dance patterns for the dance of the Swans and that of the Satyrs and Apes were omitted 'for the sake of brevity' ('avertendosi che per breuità). 9 Many of the English printed masque texts were relatively inexpensive, selling for two or three pennies if covering two sheets of paper, or four to six pennies for three or more sheets; that is, the same price as two to six loaves of bread. ${ }^{\text {IO }}$ Any form of choreographic notation would have greatly increased the length of these texts, and their costs, thereby perhaps reducing the commercial attractiveness of such a publication.

Often a very short time delay (or indeed none at all if a text was distributed at a performance) occurred between the performance of a masque and the printing of the masque text. Samuel Daniel's 1604 masque, The Vision of Twelve Goddesses, for example, was performed at court on 8 January. Twentyfive days later a pirated copy of the text was already circulating, and within the calendar year Daniel himself felt compelled to publish his own version of the text. In I605 Dudley Carleton used the imminent appearance of a printed text of The Masque of Blackness as an excuse not to describe the masque in detail to the recipient of his letter, John Chamberlain. ${ }^{\text {II }}$ The inclusion of choreographic information and/or description could have potentially increased the time it would take for a record of the masque to appear in a printed form. While Emilio de' Cavalieri's ballo was performed in May 1589, the publication by Cristoforo Malvezzi of the text and music for the six intermedi and the choreography of the final ballo did not appear until 159I. Given the relative frequency of masque production both within and outside the court between approximately 1600 and 1640 , perhaps time prohibited the preparation of a complete account of a spectacle, such as that published by Malvezzi for the I589 wedding celebrations.

Yet in spite of all these commonsense factors that militate against the inclusion of choreographic description in the masque texts, equally strong arguments push for such an inclusion. Masques commonly alluded to current political events, and this 'newsworthy' aspect of these spectacles generated intense interest. ${ }^{12}$ The crucial question, therefore, is whether the dance masters used their choreographies to allude to political events; that is, were the main masque dances also 'purveyors of news'? In her analysis of $\mathrm{Mr}$ 
Isaac's I7I3 birthday dance for Queen Anne, The Pastorall, Linda Tomko has rigorously demonstrated how Isaac, through his choreography — for instance by the use of particular steps and step sequences, by subtle modifications to steps, and by the creation of specific floor patterns - makes reference to the political stance of Queen Anne and her views of political parties. ${ }^{13}$ While scholars can more easily discern political commentary in Isaac's choreography because the dance was published in Feuillet notation, thereby ensuring we have a very detailed record of the steps and floor patterns, the lack of any surviving choreographies from the early seventeenth century does not necessarily indicate that such political commentary was absent from these choreographies when they were performed. As Margaret McGowan has remarked on the ballet performed at the French court in February 1580, a performance attended by the English ambassador Lord Cobham and his wife, this 'performance displayed, through dance, the current political tension between the two countries and emphasized French disapproval of Spanish aggression'. ${ }^{14}$ While no choreographic records from this ballet survive, those who saw it were in no doubt as to its political intentions. Given the attitude to dance by Catherine de' Medici in sixteenth-century France, and in seventeenth-century England by Queen Anna, surely it is not inconceivable that a century before Isaac composed The Pastorall, choreographers who were then working at the English court also had similar aspirations for their art? As Tom Bishop has remarked:

In a bureaucratic and technological age, or an academic milieu, we may forget how much authority as a living bodily presence was important to earlier polities. Important statements of policy were made through its exercises, its tastes, its touches, and its posture. ... Any account of the masque in performance that rests content with the static elaborations of emblem and motto without fixing its eye on the kinetic suasiveness of the dancing figure will miss much of this central

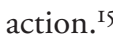

Dance masters from the fifteenth century onwards were not isolated from, nor unaware of, trends in contemporary artistic thought. They wanted their art to participate in and to reflect current intellectual concerns. Dance masters were concerned to give meaning to their choreographies, to ensure that the dance practice they advocated was more than just a set of physical skills, and that the choreographies they created represented something more than a fleeting parade of pleasing patterns. The fifteenth-century Italian dance mas- 
ters were fully aware that for dance to be included (through its association with music) in the liberal arts, it had to be understood both on a physical level and at an intellectual level. The three Italian dance masters who wrote treatises were active during the forty years from the I430s onwards, while their treatises were all written (in one version at least) by the mid I46os. These decades saw a flowering of this art, and the intellectual climate that influenced the maestri di ballo, therefore, was the world dominated by such men as Leonardo Bruni, Vittorino da Feltre, Lorenzo Valla, Guarino Guarini, and Leon Battista Alberti, public figures who were influential in the literary, philosophical, artistic, and political affairs of the first half of the fifteenth century. It was in a world dominated by the concerns and preoccupations of men such as these that the dance masters lived and worked, adapting their choreographies and professional activities to the intellectual agenda set out by Alberti and his colleagues. ${ }^{16}$

The reaction of dance masters to contemporary intellectual concerns was not unique to fifteenth-century Italy, as it continued into the sixteenth century in the work of Fabritio Caroso. On the title page of his revised dance treatise Nobiltà di dame, published in Venice in I600, Caroso speaks of his 'newly corrected' dances that have been improved since their first appearance in Il ballarino, nineteen years earlier. ${ }^{17}$ The corrections introduced by Caroso primarily involved introducing balance, repetition, and regular shapes; that is, changes which show affinity with the wider sixteenth-century intellectual discourse on the arts, and reflect the concepts found in the earlier writings of Vitruvius and Leon Battista Alberti. ${ }^{18}$ Caroso was neither unaware of, nor isolated from, current debates on artistic matters, as shown by his concern to provide a theory or set of rules for designing choreographies that were both articulated and written down, and also conformed to the prevailing theory of beauty in the other arts, in order that his choreographies would also be judged to be perfect and to epitomize grace and beauty.

From the mid-sixteenth century onwards the intellectual climate in both continental Europe and England fostered an interest in symbols. Indeed, the 'manipulation and interpretation of symbols became a popular intellectual sport in the sixteenth century'. ${ }^{19}$ Symbols were seen as having a great power both to draw heavenly power down to earth, and to help raise human understanding closer to a knowledge of the divine. The choreographies created for the sixteenth-century French court festivities, as well as for the Stuart masques, were based on geometric figures and patterns all of which had cosmic, allegorical, and moral significance. Dance masters built the dance around a series 
of discrete geometric figures or patterns that continually changed over the course of the dance. Each different re-arrangement of the geometric shapes of a circle, square, triangle, or symbol such as a cross, produced a new dance figure with a different meaning. Dance masters saw themselves as architects responsible for the design of a dance, in geometric and proportional terms, and for these choreographers the true beauty of their dances resided in the geometric figures. Geometrically patterned choreographies were one way in which cosmic influences could be magically (that is, in a hidden or occult manner) transported to earth and, once there, could induce the same cosmic harmony to operate on earth. ${ }^{20}$

Given the history of 150 or more years' involvement by dance masters from Italy, England, and France in contemporary intellectual concerns and their creation of choreographies with allegorical and moral significance, most likely the masque choreographers did create dances that shared the concerns articulated in other elements of the masque. If they did not, then the topicality of a masque would have been seriously diluted, given that their choreographies constituted such a major portion of the spectacle. If the choreographies did contain such meanings then one would expect that those who were not able to attend the actual performance would be eager also to know the details of the choreographies, as well as the plot and text of the songs, the costumes, stage designs, and names of the elite performers.

Another factor one would expect to increase the recording of some form of choreographic record, even if only in an informal mode, was the long rehearsal period of the dancers, a period that frequently went for five to six weeks. The dance masters for Oberon, Nicolas Confesse and Jeremy Herne, for example, were paid for six weeks' work and rehearsals, while for the I6I7 masque, The Vision of Delight, the dancers rehearsed for fifty days. ${ }^{2 \mathrm{I}}$ Long rehearsal periods for the dance performers were not unique to England. A similar situation existed in sixteenth-century France, where ambassadors and state officials uttered many complaints that no business could be conducted because the king and his courtiers were "most busy with their dancing"'. ${ }^{22}$ The rehearsal period for these French spectacles was usually a matter of weeks, not days, as the dancers were very serious about maintaining high standards for each performance, and none wished to appear in front of their peers ill-prepared. ${ }^{23}$ Both English and French dance performers were thoroughly conversant with the styles required: they had studied dance several hours a day from childhood, and were skilled, and in some cases, very skilled dancers. Therefore, one has to ask: did any of the dancers record the step sequences, or floor 
patterns, or diagrams of the dance figures during these weeks of rehearsal? In his book on The Essex House Masque, Timothy Raylor has argued that the source of the manuscript text of this masque was far more likely to have been a performance text belonging to one of the young gentlemen masquers who danced at the performance on 8 January I62I, rather than a retrospective account that had been prepared for presentation or publication. ${ }^{24}$ We thus have a precedent for a gentleman masquer providing information and/or a performance text to a relative who wished to produce a manuscript of the masque for his family's records. Is it possible that other dancers provided choreographic information to interested relatives? This last question leads into the second section of this essay in which I examine what evidence exists for any unpublished records of the masque choreographies.

On 2 February 1604 Edward Somerset, fourth Earl of Worcester, privy councillor and valued advisor of James I, wrote to the Earl of Shrewsbury, also a member of the Privy Council, about the latest court news, including the masque he had seen at court one month earlier, Samuel Daniel's The Vision of Twelve Goddesses:

Whereas youer Lo. saythe your wear never perticulerly advertised of the Maske, I have been at $6 d$. charge with youe to send youe the booke, which wyll inform youe better than I can, having noted the names of the Ladyes applyed to eche Goddes; and for the other, I would lykewyse have sent youe the ballet, yf I cowld have got yt for money; but these bookes, as I heare, are all cawled in, and in truthe I wyll not take uppon mee to set that downe whiche wyser then myself doe not understand. ${ }^{25}$

His sentence about the masque, quoted in full above, is the only reference to this event in the letter, and as it stands the meaning of the second half of the sentence is not entirely clear, the crucial phrase being 'and for the other, I would lykewyse have sent youe the ballet, yf I cowld have got yt for money; but these bookes, as I heare, are all cawled in'. Different interpretations of this phrase have been offered, since questions will always remain as to first whether the Earl of Worcester was talking about two court events or just one, and second exactly what he meant by the word 'the ballet': a book of the music for the masque, or a book of the choreography. ${ }^{26}$

In early seventeenth-century England 'ballet' was one of the many alternative spellings of the word 'ballad'. By the mid-seventeenth century the word 'ballet' in English had become a specific term for a dance or a ball. ${ }^{27}$ The ante- 
cedents of the word 'ballad' in Old French, Italian, Catalan, and Portuguese, however, all referred to a dance or dancing, or a popular poem or song for dancing, ${ }^{28}$ while the Oxford English Dictionary cites three examples from the sixteenth century in which 'ballad' is used in English works to refer to 'a song intended as the accompaniment to a dance'. ${ }^{29}$ The association between the word 'ballad' (and one of its alternative spellings 'ballet') and dancing in the minds of early seventeenth-century English speakers would be strengthened by the publication in England of foreign language dictionaries in this period. In John Florio's $A$ Worlde of Wordes published in London in 1598 the Italian word 'ballata' is defined as 'a ballade, a song, a gigge, a roundelaie'. 30 Florio thus equates a ballad with two dances: a jig and a roundelaie. ${ }^{3 \mathrm{I}}$ The boundaries between dancing and a 'ballad', a song used to accompany dancing, seem to be quite fluid at this period. Further arguments point to the knowledge and use of 'ballet' by English speakers to mean dance circa I6oo. Significantly Randle Cotgrave's French dictionary defines 'ballet' as 'a dauncing. ${ }^{32}$ Consideration should be given to the presence of French dance masters and musicians at the English court, as well as the observation and description of danced spectacles (or ballets as their French hosts called them) at the French court by visiting English ambassadors and delegations for at least the preceding thirty years. All of these circumstances would have familiarized English speakers with the French use of 'ballet' as referring to dancing.

After taking the preceding arguments into consideration surely one feasible interpretation of this letter is that by his use of the word 'ballet' the Earl of Worcester was referring to a record — of some sort - of the choreographies in Daniel's masque. If this possibility is accepted then several interesting implications arise from this view. First, these words imply that there were 'bookes' or some sort of written record of the masque dances and that this choreographic record was separate and distinct from the record of the spoken text of the masque; second, that these books were potentially available for purchase; and last, that more than one copy of the book or written record of the choreographies circulated. This letter furthermore implies that Somerset expected that a record for the choreographies should have been available for him to send with the text of the masque. Nothing indicates that the presence of these books for the ballet was a unique or extraordinary occurrence for this masque in particular. While a great deal of evidence pertaining to the distribution of masque texts survives, this letter is one of the few pieces of evidence that suggest a record of the masque choreographies also once existed. 
The same passage also raises several intriguing questions about the creation of these books. Somerset wrote 'but these bookes, as I heare, are all cawled in'. Who called these books in, and why were they called in? The phrase 'calling in' was used at this time by printers who had found errors in the printed text, and also by censors who did not want a book distributed. Whether either group was involved in this particular case is unclear. Who gave Somerset the information that the books had been recalled, and who wrote the original book or record of the 'ballet'? Was it the choreographer of the masque, or another person, and was this author the same person who made multiple copies of the original document so that Somerset in his letter could refer to 'bookes' in the plural? If the Earl of Worcester, a nobleman, courtier, and privy councillor, was not able to obtain a copy of this material, then, one wonders, who could? Furthermore, of what did the book of the ballet consist? Was it a general description of the dances and the underlying conceit, with a few general descriptions of the patterns of the dances? Or was it a more detailed record of the choreographies with specific information as to the step sequences, floor plan, and dance figures of the masque dances? Or did the book contain a separate set of instructions for each dancer, just as if it were an actor's part-book?

One would have to assume that the books which were called in contained a far more substantial amount of information on the choreography than was present in Daniel's published text, as the choreographic information given by Daniel is sparse. ${ }^{33}$ If they did not, then these books would not have contributed much to an understanding of the dance performances, and there would have been no point in Somerset's trying to obtain a copy of the book of the ballet to send to the Earl of Shrewsbury.

In the period between I627 and I633 the poet Georg Rudolf Weckherlin, who was secretary to Lord Conway the then Secretary of State, composed two drafts for a masque he had devised for Henrietta Maria. In one of the drafts Weckherlin included a diagram of the opening formation of the 'grand ballet' which would end the masque. ${ }^{34}$ While his proposal did not come to fruition, Weckherlin had had a successful career as an author and producer of masques for the Duke of Württemberg's court at Stuttgart from I616 to I618. As part of his duties as secretary to the duke, Weckherlin not only created several ballets but he also produced detailed accounts of the festivals in these three years. 35 The record for the 1618 festival included an engraving of the twelve male dancers at one moment of the ballet, as well as images of seven of the choreographic figures performed by the twelve dancers. Thus Weckherlin 
had had personal experience of one of the common forms of dance notation at that time. One can only speculate as to whether Weckherlin would have produced a similar record of his proposed ballet for Henrietta Maria if it had gone ahead. But the requirement for a draft of a dance master's ideas for his proposed masque choreographies to present to the royal, or noble, instigator of a masque must have been common, especially given the royal interest in the creation of danced spectacles, as well as in their performance in them. This very procedure Beaujoyeulx claims happened in the creation of the Balet Comique, where the queen of France ordered him 'to draw up a plan for her' ('luy dresser quelque dessein'). Beaujoyeulx continues: 'When I had written it [the plan] out I immediately went back to the court to present it to the Queen ... Her Majesty, after having me read the discourse in the presence of several princesses and ladies who were with her - when my work had been examined, commanded me to carry out my plan forthwith. ${ }^{36}$

Among the surviving records from the 1634 Inns of Court masque, The Triumph of Peace, are documents in the hand of Bulstrode Whitelocke, ${ }^{37}$ who was a member of, or had links with, several of the subcommittees set up to deal with parts of the spectacle..$^{38}$ Among these documents are seven diagrams that show the arrangements of the musicians and singers at various times during the performance. All seven depict geometrical arrangements, 39 and two of these diagrams consist of dots, one of which is diamond-shaped, and the second, which is a more complicated but symmetrical arrangement. 40

If lists and diagrams were produced for the relevant subcommittee that showed the placement of the musicians, surely even more crucial would be diagrams showing the arrangements of the dancers? Bureaucrats in charge of organizing an event always require documentation, especially when monies are being dispersed. Would not the subcommittee in charge of dancing therefore have required written documents to outline, or to detail, what was being proposed by the dance masters Sebastian La Pierre and Etienne Nau? Certainly the sums being paid to these two men were quite large; that is, one hundred pounds each, equal to that paid to the composers William Lawes and Simon Ives. ${ }^{4 \mathrm{I}}$ Peter Walls has concluded that these diagrams 'represent not a record of final decisions about blocking so much as sketches made in the course of discussions with the music committee'. ${ }^{42}$ If the music committee required sketches, would not the dance subcommittee have followed a similar course?

Representing the position of dancers as dots was a common practice at this time, particularly in northern European dance manuscripts. The best 
illustration of this practice is the notebook of a French dance master who was working in Brussels circa I6I4-19, which contains twenty-seven folios of over four hundred and fifty dance figures for five to sixteen dancers recorded in this manner. ${ }^{43}$ These figures can be divided into several categories. The largest category comprises figures whose name is descriptive of their shape, and whose shape represents a physical object, such as 'batoir' (bat), 'ceur' (heart), 'croi' (cross) or 'estoille' (star). The second category is composed of figures in the form of geometrical shapes, the prime example in this category being the pyramid figures, and the figures in the shape of a lozenge or diamond. The third main category of figures is made up of composite figures in which discreet geometric shapes are combined to form a larger shape; for example, a star formed by a circle and four triangles, a star with four triangles and a lozenge at its centre, or a lozenge created with four triangles. Many of the figures in this notebook are recorded in two ways, with one being the reverse of the other; for example, pyramids whose apex is at the top of the page, and reverse pyramids whose apex points towards the bottom of the page. Composite figures are also treated in the same manner. The presence of so many reverse images of individual figures is significant, as it points to the fact that the notebook is a relatively systematic record and codification of a large number of different shapes which could be used by a dance master in the creation of a newly-composed choreography for a court spectacle. 44

La Pierre and Nau who choreographed dances for The Triumph of Peace were French, as were about half of the dance masters working in early Stuart London, and most of these men were connected with the court. ${ }^{45}$ In the I6IOs and I620s the French court employed dance masters such as Noel La Motte and Jacques Cordier, the latter of whom continued in Henrietta Maria's employment after she moved to England in $1625.4^{6}$ The knowledge of continental European dance notation practices among the dance masters responsible for masque choreographies in England therefore would have been high. Ben Jonson himself was not unaware of European precedents in publishing full accounts of danced spectacles, as he owned a copy of Beaujoyeulx's 158I Balet Comique. 47 One has to ask the question: why were French models of choreographic description and publication not followed in England? Or, to put the question another way, what were the characteristics of the I58I French ballet, and the 1589 Florentine intermedi that assisted the publication of these two dance spectacles, publications which included far more choreographic information than was the case in the English masque texts, both printed and manuscript? 48 
The first characteristic shared by the 1580 s spectacles, but not by the English masques, was the fact that in the two former events the producer and/or director of the multi-media events also choreographed the dances. Both Beaujoyeulx and Cavalieri were responsible for the choreography, and therefore, perhaps, had more incentive and interest in recording their own creations and contributions as well as those of their collaborators. Certainly both these gentlemen, being the creators of the choreographies, would have had a very detailed and clear knowledge of what was performed, and would have had few problems in transferring that knowledge to paper. ${ }^{49}$ In previous spectacles at the French court, for example at Bayonne in 1565 and Fontainebleau in 1564 , the proceedings were directed not by the choreographer but by the poet, who 'dictated to other artists the content of their work'. $5^{\circ}$ Thus the Balet Comique departed from earlier models in this respect, and this departure may have contributed towards the publication of this choreographic record. Both Beaujoyeulx and Cavalieri were also musicians, and so would have been in a position to check both the musical and the choreographic 'text' as it appeared on the proof pages.

A second suggestion as to why dance and music were both afforded a far more prominent place in the published description of the Balet Comique than in the Jacobean and Caroline masques was Beaujoyeulx's association with the work and aims of Antoine de Baif's Académie de Poésie et de Musique. ${ }^{\mathrm{I}}$ The choral music in this work was written in the style of musique mesurée, and Beaujoyeulx made it clear in his 'Explanation to the Reader' that he was concerned with presenting an artistic work that combined the effect of both music and dance. 'I decided it would not be a bad idea to mix one and the other together and to diversify the music with poetry and weave music into the poetry, and most often to merge the two together; for in antiquity they never recited poetry without music, and Orpheus never played without words. I have, however, given first place and honour to the dance'.52 Baif and Pierre de Ronsard both contributed verses to the Balet Comique, while Lambert de Beaulieu, who composed the music, was also a member of Baif's Académie. 53 The Balet Comique was therefore specifically aligned with an organized intellectual circle of poets and musicians, who, for over a decade, had been concerned with exploring and demonstrating the enhanced power of music when combined with other arts to affect the emotions of the listeners, or spectators. 54 An association with a formal organization like Baif's Academy may have provided much more of an incentive to get the description of the dances included in the publication of the spectacle, far more than 
if the work were only tied to one individual's desire for self-promotion. The association with, and/or participation in, a recognized intellectual movement that counted among its supporters men of wealth and position in society may have also eased any financial burden associated with publishing a long and detailed description of a spectacle. Not a great deal is known about the lives of the dance masters who worked for the English court in the first four decades of the seventeenth century, but what is known does not suggest that they were in a position of underwrite or to engage in large-scale publishing ventures.

The Stuart masques were multi-media spectacles, at which the majority of the time was devoted to dancing, and yet the choreographic information which has survived from all these performances is slight. While contemporary interest in the masques was intense, with printed and manuscript copies of the text of the masque circulating within the ambit of the court as well as outside of it, specific choreographic information was omitted from these texts. This paradox lies at the heart of this essay; that is, why were the dances seemingly ignored in the printed and manuscript masque texts that we know today, given that contemporary interest in the dances and the dance performances was so high? When we consider the wider picture of the dance masters and their activities in Italy and France as well as England, however, commonsense reasons for such an omission are obvious; yet we also find equally strong arguments for the inclusion of choreographic information. Perhaps our modern assumption of the absence of contemporary choreographic records is a little premature, and indeed more choreographic information may have been recorded than we have hitherto realized.

\section{Notes}

An earlier and shortened version of this essay was first presented at the Renaissance Society of America's annual conference, 3-5 April 2008. I would like to thank Mary Chan, Margaret McGowan, and Jennifer Thorp for their helpful and insightful comments on the earlier version of this essay, and also the journal's two anonymous readers whose suggestions improved the final version, as well as Barbara Ravelhofer and Linda Phyllis Austern for their thoughts on the Earl of Worcester's letter.

I Lauren Shohet, 'Reading/Genres: On i6zos Masques', in Robert E. Stillman (ed.), Spectacle and Public Performance in the Late Middle Ages and the Renaissance (Leiden, 2006), 235 . 
2 John Finet, Ceremonies of Charles I. The Note Books of John Finet I628-164I, Albert J. Loomie, S.J. (ed.) (New York, I987), I49.

3 Lauren Shohet, 'The Masque as Book', in Ian F. Moulton (ed.), Reading and Literacy in the Middle Ages and the Renaissance (Turnhout, 2004), I56-7.

4 Ibid, I50.

5 Barbara Ravelhofer, The Early Stuart Masque: Dance, Costume and Music (Oxford, 2005), 98, I5.

6 'Questo ballo sarà principiato da Sette Persone; cioè Quattro Dame, e Tre Huomini ... \& insieme col pie sinistro faranno la Riuerenza, \& à man sinistra le continenze, e una Riuerenza à man sinistra, e.2. cangi co’l pie sinistro, \& uno seguito trangato auanti, \& uno in dietro, e dipoi tutti in ruota à man sinistra col pie sinistro quattro spezzate, \& altre quattro scorse ritornando al suo luogo'. Cristoforo Malvezzi, Intermedii et concerti fatti per la commedia rappresentata in Firenze nelle nozze del serenissimo don Ferdinando Medici, e madama Christiana di Loreno, gran duchi di Toscana (Venice, I59I), ninth book, p. 2I.

7 For comparison purposes, see below at note 33 for an example of the choreographic information included in the masque texts.

8 For a reconstruction of Emilio de' Cavalieri's choreography, with diagrams of the floor track and the alignment of the steps with the music, see Jennifer Nevile, 'Cavalieri's Theatrical Ballo 'O che nuovo miracolo': A Reconstruction', Dance Chronicle 2I.3 (1998): 353-88. For an analysis of this choreography and a discussion of its relationship with the wider dance practice of the time, see Jennifer Nevile, 'Cavalieri's Theatrical Ballo and the Social Dances of Caroso and Negri', Dance Chronicle 22.I (I999): II9-33.

9 Roland Jackson (ed.), A Neapolitan Festa a Ballo. 'Delizie di Posilipo Boscarecce, e Maritime' (Madison, I978), $\mathrm{xx}$.

IO Shohet, 'The Masque as Book', I6I-2.

II 'The maske at night requires much labor to be well described, but there is a pamflet in press w[hi]ch will saue me that paynes.' Ben Jonson, Works, C.H. Herford and Percy and Evelyn Simpson (eds) (Oxford, I950), I0.449.

I2 For a discussion of the political content of Daniel's The Vision of Twelve Goddesses see Peter Holbrook, 'Jacobean Masques and the Jacobean Peace', The Politics of the Stuart Court Masque, David Bevington and Peter Holbrook (eds) (Cambridge, 1998), 72-8; for an emphasis on Queen Anna's political purposes behind her masquing, see Leeds Barroll, 'Inventing the Stuart Masque', in the same volume, I24-31. For a discussion of the current political content in The Triumph of Peace, a masque which Shohet describes as 'one of the most thorough in its commentary upon political questions of interest', see Shohet, 'The Masque as Book', I50-2. For Catherine de' Medici's use of 
dance as a deliberate political tool in her domestic and international foreign policy, see Margaret M. McGowan, Dance in the Renaissance: European Fashion, French Obsession (New Haven and London, 2008), especially I28-32.

I3 Linda J. Tomko, 'Mr Isaac's The Pastorall and Issues of "Party"', in Jennifer Nevile (ed.), Dance, Spectacle, and the Body Politick, I250-I750 (Bloomington, 2008), 24I-62.

I4 McGowan, Dance in the Renaissance, I3O.

I5 Tom Bishop, 'The Gingerbread Host: Tradition and Novelty in the Jacobean Masque', in David Bevington and Peter Holbrook (eds), The Politics of the Stuart Court Masque (Cambridge, 1998), 97-8.

I6 For an extensive discussion of the humanist influences on the fifteenth-century Italian dance masters, see Jennifer Nevile, The Eloquent Body: Dance and Humanist Culture in Fifteenth-Century Italy (Bloomington, 2004).

I7 Fabritio Caroso, Il Ballarino, I58I, Venice, facsimile edn, Broude Brothers (New York, 1967); Fabritio Caroso, Nobiltà di dame, Venice, I6oo, facsimile edn, Forni (Bologna, 1980).

I8 For a discussion of specific changes in Caroso's choreographies, see Jennifer Nevile, "'Rules for Design": Beauty and Grace in Caroso's Choreographies', Dance Research 25.2 (2007): 107-18.

19 Nicholas Clulee, John Dee’s Natural Philosophy Between Science and Religion (London, 1988), 77.

20 See Thomas M. Greene, 'Labyrinth Dances in the French and English Renaissance', Renaissance Quarterly 54.4.2 (200I): 1403-66.

2I Ravelhofer, The Early Stuart Masque, 75.

22 McGowan, Dance in the Renaissance, 30.

23 On this point see ibid, 8I-7, I70.

24 This young man was a relative of Gervase Holles who was responsible for transcribing the masque text. Timothy Raylor, The Essex House Masque of I62I: Viscount Doncaster and the Jacobean Masque (Pittsburgh, 2000), 5-II.

25 John Nichols, The Progresses, Processions, and Magnificent Festivities of King James the First, 4 vols. (London, I828; rpt New York, nd), I.317.

26 Some scholars have seen the whole sentence as referring to Daniel's masque, while others have interpreted 'the ballet' as a reference to the masque performed at court on I January I604. The masquers in this spectacle were all young but politically insignificant nobles most of whom were gentlemen of the bedchamber. No record of this masque has survived except for comments by observers. For a discussion of these contemporary observations, see Barroll, 'Inventing the Stuart Masque', I24-6. Oxford English Dictionary Online, 'ballet, n.I'.

28 Ibid, 'ballad, n.I (Etymology and Spellings)'. 
29 Ibid, 'ballad, n.2'. The examples are from 1508 , I545, and 1549.

30 John Florio, A Worlde of Wordes (London, I598). Facsimile edn (Hildesheim, 1972), 37 .

3I For example, in the last scene of the anonymous drama The Maydes Metamorphosis (I600) 'roundelay' is used to describe dancing activity. (See the electronic database Literature Online accessed on 2 December 2008 at <http://info.library.unsw.edu.au/ cgi-bin/local/access/access.cgi?url=http://lion.chadwyck.co.uk>.)

32 Randle Cotgrave, A Dictionarie of the French and English Tongues (London, I6II). Facsimile edn (Hildesheim, 1970).

33 '[T]he Goddesses ... returned down into the midst of the hall, preparing themselves to begin their dance, which, as soon as the Graces had ended their song, they began to the music of the viols and lutes placed on one side of the hall. Which dance being performed with great majesty and art, consisting of divers strains framed unto motions circular, square, triangular, with other proportions exceeding rare and full of variety, the Goddesses made a pause, casting themselves into a circle, while the Graces again sang to the music of the temple, and prepared to take out the Lords to dance. With whom after they had performed certain measures, galliards, and corantos, Iris again comes ... : whose speech ended they drew themselves again into another short dance with some few pleasant changes', A Book of Masques. In Honour of Allardyce Nicoll (Cambridge, 1967), 29-30, 11.170-80.

34 For a discussion of these two drafts, see Leonard Forster, 'Two Drafts by Weckherlin of a Masque for the Queen of England', German Life and Letters, new series I8.4 (1965): 258-63. In 1965 the drafts were held among the Trumbull manuscripts owned by Lord Downshire, but they are now held in the British Library, Additional MS 72439. I would like to thank Jennifer Thorp for locating the present repository of these documents.

35 Sara Smart, 'The Württemberg Court and the Introduction of Ballet in the Empire', in J.R. Mulryne, Helen Watanabe-O'Kelly, and Margaret Shrewring (eds), Europa Triumphans: Court and Civic Festivals in Early Modern Europe, 2 vols (Aldershot, 2004), 2.35.

36 Translation by Carol and Lander MacClintock from Le Balet Comique de la Royne, I58I, (np, I97I), 35. 'finablement ie m' arrestay sur le dessein, qui depuis a esté mis à execution: le quel ayant redigé par escript, ie retournay aussi tost en Cour, le presenter à la Royne, ... Saditte maiesté m’en aya[n]t deslors faict lire le discours, en la presence de plusieurs princesses \& dames qui se trouuerent pres d'elle: \& mon œuure ayant esté examiné, saditte maiesté me commanda de promptement l'executer', Balthazar de Beaujoyeulx, Le Balet Comique de la Reyne (I58I), Facsimile edn, Margaret M. McGowan (ed.) (Binghamton, NY, I982), Aii. 
37 Longleat House, Whitelocke Papers, Parcel II, No. 9 (Items I-I9).

38 Peter Walls, Music in the English Courtly Masque, I604-I640 (Oxford, I995), I66-7.

39 Murray Lefkowitz, 'The Longleat Papers of Bulstrode Whitelocke: New Light on Shirley's Triumph of Peace', Journal of the American Musicological Society I8.I (I965), 56.

40 Andrew J. Sabol, 'New Documents on Shirley's Masque "The Triumph of Peace", Music \& Letters 47.I (1966), I7.

4I Walls, Music in the English Courtly Masque, I6o.

42 Ibid, I72.

43 Stockholm, Kungliga Biblioteket, Cod. Holm S253. The manuscript itself covers I22 folios on which are dance music (entrées, courantes, allemandes), written descriptions of the plots of various ballets (for example, f. $2 \mathrm{r}-2 \mathrm{v}, 4 \mathrm{r}-4 \mathrm{v}, \mathrm{f} .45 \mathrm{r}$ ), songs, poems and other items such as instructions for making fireworks (for example, f. 35v-36r), or a method of fumigating houses in times of the plague (f. $38 \mathrm{v}$ ). The manuscript begins with a list of the subjects for ballets (f. Ir), followed by written descriptions of ballet plots (f. $2 \mathrm{r}-2 \mathrm{v}$ and $4 \mathrm{r}-4 \mathrm{v}$ ), and then numerous drawings of figures for five to sixteen dancers, many of which are named. After the figures for sixteen dancers, there are three folios (f. 26r-27r) in which the dance master gives the letters of the alphabet as they are formed by groups of dancers, from as few as ten performers to as many as twenty-three dancers for some letters.

44 For a more detailed analysis of the figures in this manuscript and their meaning, see Jennifer Nevile, 'Dance Patterns of the Early Seventeenth Century: The Stockholm Manuscript and Le Ballet de Monseigneur de Vendosme', Dance Research I8.2 (2000): I86-203.

45 Ravelhofer, The Early Stuart Masque, 61.

46 Ibid, 5I-2.

47 Ibid, 197.

48 Obviously the desire to re-create the splendour of a spectacle for those who were not able to be present would cross geographic and chronological boundaries.

49 In one of the poems printed before the text of the Balet Comique, Beaujoyeulx is praised for his inventiveness in the creation of dance patterns, and for his scholarliness and his re-creation of the art of ancient Greek dance (McGowan, 'Introduction', Le Balet Comique de la Reyne, I58I, Margaret M. McGowan (ed.) (Binghamton, N.Y, I982), 26). 'Beavioyevx, qui premier des cendres de la Grece / Fais retourner au jour le dessein \& l'adresse / Du Balet compassé en son tour mesuré, Qui d'vn esprit diuin toy-mesme te deuance, / Geometre, inuentif, vnique en ta science'. (Beaujoyeulx, Le Balet Comique de la Reyne, I58I, e.j.) See also Greene, 'Labyrinth Dances', I420-3.

50 Margaret M. McGowan, 'Introduction', 37.

5I Ibid, 24-5. 
68 Jennifer Nevile

52 Translation by Carol and Lander MacClintock from Le Balet Comique de la Royne, I58I, (np, I97I), 33. 'Sur ce ie me suis aduisé qu'il ne seroit pint indecent de mesler l'vn $\&$ l'autre ensemblément, \& diuersifier la musique de poesie, \& entrelacer la poesie de musique, \& le plus souuent les co[n]fondre toutes deux ensemble: ainsi que l'antiquité ne recitoit point ses vers sans musique, \& Orphee ne sonnoit iamais sans vers. I'ay toutes fois donné le premier tiltre $\&$ honneur à la dance.'

53 McGowan, Dance in the Renaissance, II7.

54 For further discussion on the aims of Baif's Academy and the experiments through which Baif and his colleagues attempted to realize these aims, see D.P. Walker, 'The Aims of Baif's Académie de Poésie et de Musique', Journal of Renaissance and Baroque Music I (1946-47), 9I-IOO, and McGowan, Dance in the Renaissance, 4I-5. 